\section{Marketing strategies in the internationalization process of Brazilian franchises}

\author{
Maria Adriana A. P. Camargo \\ Thelma Valéria Rocha \\ ESPM, PMDGI, São Paulo, Brazil \\ Susana Costa e Silva \\ Universidade Católica Portuguesa, \\ Católica Porto Business School, Porto, Portugal
}

Received on

$11 / 02 / 2015$

Approved on

$11 / 02 / 2015$

Responsible editor:

Prof. Dr. Guilherme de Farias

Shiraishi

Evaluation process:

Double Blind Review

\begin{abstract}
Purpose - This paper aimed to analyze the influence of marketing strategies on the internationalization process of Brazilian franchises. The objective was to identify the marketing strategies used by Brazilian franchises during different stages of their internationalization processes and to analyze these strategies according to the Global Marketing Strategy (GMS).
\end{abstract}

Design/methodology/approach - The paper adopted a qualitative research methodology based on three case studies developed in Brazilian franchises in the footwear and apparel sector: two companies with active involvement and one with commitment involvement abroad. Six directors and marketing managers of these companies provided statements regarding the internationalization process and marketing strategies.

Findings - The Brazilian franchises are on the path towards standardizing their marketing mix, but they are still a long way from leading their business actions to the four final dimensions of the GMS: concentration and coordination of marketing activities, integration of competitive movements and participation in the global market. Secondly, we performed a comparative analysis of the three case studies considering active and commitment involvement.

Originality/value - This study innovates using the GMS to analyze the internationalization processes of Brazilian franchises in different stages, and it emphasizes the dimensions that should be subjects of planning for firms that are preparing to grow their franchising business models abroad.

Keywords - international marketing; international franchising; global marketing strategy; franchises; Brazilian franchises.

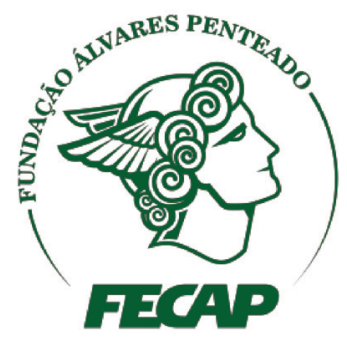

Review of Business

Management

DOI: $10.7819 /$ rbgn.v18i62.2804 


\section{Introduction}

In Brazil, revenues from the franchise sector in 2015 were approximately BRL 139 billion, which is an increase of approximately $13 \%$ compared to 2014. In the global context, Brazil ranks $6^{\text {th }}$ relative the number of franchises, with 114,409 units in 60 countries, mainly in the US and Portugal (Guide Franchising, 2016).

According to a guide for franchising (Associação Brasileira de Franquias [ABF], 2016, p. 8) from ABF (Brazilian Franchising Association), "Brazil already has 134 franchises in operation abroad in 2015; this number is $20 \%$ higher than in 2014". These overseas operations are still minor compared to the Brazilian market, but they represent an appealing challenge for managers regarding concerns about profitability and growth. According to ABF (2016), only 5\% of Brazilian franchises pursue internationalization, and many others prefer to target local expansion before deciding to internationalize.

According to Melo, Andreassi and Oliveira (2012), Brazilian franchises use different entry modes in international markets, such as owned units, direct franchises, master franchises or join ventures, and the choice of a particular entry is linked to the levels of control, international strategies and investment abroad.

The choice of this strategy is also based on: (1) the time required for recovery of investment; (2) the level of control desired in foreign operations; (3) the scaling of resources available for international expansion; and (4) the flexibility that will be given to local partners (Sanghavi, 2003).

In addition to the choice of strategy, it is also necessary for Brazilian franchises to decide on the marketing strategy to be used in the internationalization process.

When a company operates in foreign markets, marketing activities have a strong influence on the creation of competitive advantages and implementation of the strategy of the company.
In this context, this paper analyzes the internationalization process of Brazilian franchises, with an emphasis on these firms' marketing strategies. The aim is to identify the marketing strategies used by Brazilian franchises in two stages of the internationalization process: active involvement and commitment involvement.

McIntyre and Huszagh (1995) developed a stages model using Uppsala Model to describe the stages of internationalization of franchising companies in the US and created four stages: domestic, experimental, active, and committed to internationalization. Rocha et al. (2014) used these stages to analyze Brazilian franchises and divided 106 franchises with operation abroad into three clusters: 51 companies with experimental involvement in only one or two countries abroad; 32 companies with active involvement in three or four countries abroad; and 22 companies with committed involvement in more than five countries abroad.

One research gap has been the identification of an emerging market context, such as in Brazil, which has been a late mover in international franchising, with regard to how companies use marketing strategies in different stages of the internationalization process.

According to Zou and Cavusgil (2002), the GMS of a company abroad has positive effects on their performance in the global market. This strategy was defined by Zou and Cavusgil (2002) as a measure that a company uses to globalize its products and its marketing in the countries in which it operates. This process is accomplished by means of marketing mix standardization, concentration and coordination of marketing activities and integration of competitor actions in the markets in which the company undertakes business. Rocha and Silva (2011) analyzed the GMS in subsidiaries of multinationals in Brazil.

In this paper, we use a qualitative method to develop three case studies. All of the companies are from the footwear and apparel sector in Brazil: two with active involvement abroad and one with committed involvement. We conducted six 
in-depth interviews with executives to investigate this subject. This papers starts with a theoretical review. Then, we formulate propositions. Next, we explain our methodology. Finally, we present our results with a discussion and present the study's conclusions.

\section{Theoretical framework}

In this section, we initially explore international franchising, and then we examine international franchising in Brazil and the stages of internationalization. Next, we address issues regarding GMS and franchising. Finally, we offer some propositions.

\section{I International franchising}

According to Ghemawat (2007), when considering a global strategy, most corporate and academic leaders make two assumptions: firstly, the main challenge is to balance economies of scale and the capacity to respond to local conditions; and secondly, companies should have the ability to operate locally and globally. These assumptions encapsulate the well-known "adaptation vs. standardization" dilemma that forms the basis of all international marketing-mix decisions.

The internationalization process of firms operating through franchising started with firms normally organized in chains in the United States of America, Europe and Canada.

For these brands operating first throughout their domestic economies, the main reason to start an internationalization process was saturation of the domestic market.

Merrilees (2014) reviewed the evolution of the theory of international franchising over the past two decades, describing 10 papers since 1990. Three time phases were identified: Phase 1 foundation theory - early 1990s; Phase 2 - deeper explanation - late 1990s; and Phase 3 - extending theory - after 2000, as shown in Table 1.

\section{Table 1}

\section{Evolution of franchising theory}

\begin{tabular}{|c|c|c|}
\hline Phases & Papers selected - Authors & Domain Theory \\
\hline $\begin{array}{l}\text { Phase } 1 \text { - foundation } \\
\text { theory - early } 1990 \text { s }\end{array}$ & $\begin{array}{l}\text { Huszagh et al. (1992); } \\
\text { Eroglu (1992) }\end{array}$ & $\begin{array}{l}\text { Theory of the firm; strategic marketing theory } \\
\text { general model of franchisor intention to internationalize }\end{array}$ \\
\hline $\begin{array}{l}\text { Phase } 2 \text { - Deeper } \\
\text { Explanation - } \\
\text { late } 1990 \text { s }\end{array}$ & $\begin{array}{l}\text { Fladmoe-Lindquist (1996) } \\
\text { Doherty and Quinn (1999) } \\
\text { McIntyre and Huszagh (1995) }\end{array}$ & $\begin{array}{l}\text { Resource-based capability theory } \\
\text { International retail franchising theory } \\
\text { Internationalization process and Uppsala model }\end{array}$ \\
\hline $\begin{array}{l}\text { Phase } 3 \text { - Extending } \\
\text { the Theory in Six } \\
\text { Directions - after } \\
2000\end{array}$ & $\begin{array}{l}\text { Quinn and Alexander (2002) } \\
\text { Doherty and Alexander (2004) } \\
\text { Altinay and Miles (2006) } \\
\text { Cheng et al (2007) } \\
\text { Aliouche and Schlentrich (2011) } \\
\text { Jell-Ojobor and Windsperger } \\
(2013)\end{array}$ & $\begin{array}{l}\text { Domestic and international retail franchising theory } \\
\text { International franchisor-franchisee relationships } \\
\text { International franchise stakeholder theory } \\
\text { Stage model of international franchising } \\
\text { Strategic model of global franchise expansion } \\
\text { Governance choice model based on transaction } \\
\text { cost and agency theories }\end{array}$ \\
\hline
\end{tabular}

Note. Adapted from "International Franchising: Evolution of Theory and Practice", by B. Merrilees, 2014, Journal of Marketing Channels, 21, 133-142.

In early 1990s, two papers were selected Huszagh, Huszagh and McIntyre (1992) and Eroglu (1992) - because they laid the foundation of the knowledge domain for international franchising.

Huszagh et al. (1992) combined the strategic competitive advantages of particular firms and the barriers to market entry of domestic franchisors in entering international markets strategically. The units of analysis were a comparison of domestic and international American franchisors. Huszagh et al. (1992) concluded that internal factors, rather than external factors, were critical determinants of the decision to introduce a franchise internationally. 
Eroglu (1992) presented his article in the same issue of the International Marketing Review but with only a theoretical perspective. $\mathrm{He}$ proposed a model to analyze the determinants and processes of the internationalization of franchise systems. His model explains the intention to internationalize as a balance between perceived benefits and perceived risk. Organizational factors, such as firm size, experience, and top management's perceptions of the firm, are considered. His model is very important and has been used in studies in Brazil, such as Marques (2006), Khauaja (2010), Melo, Borini and Cunha (2014) and others.

As shown in Table 1, Phase 2 was in the late 1990s, and we selected two papers as important: Fladmoe-Lindquist (1996) and Doherty and Quinn (1999). We also included McIntyre and Huszagh (1995) as important at that time because these authors adapted stages of internationalization, based on Cavusgil and Nevin (1980), to franchising companies in the US, using the Uppsala Model.

Fladmoe-Lindquist based her paper on resource-based and capability theories and developed a capability theory of international franchising. She developed a two-by-two matrix, with low and high levels of existing international franchising capabilities, and she included global franchising brands in the high-high cell and domestic franchisors in the low-low cell. Further, she included "born global" franchising brands as those developed to expand abroad.

Doherty and Quinn (1999) referred to the notion of international retail franchising theory and examined components such as monitoring costs, opportunism, and risk management. McIntyre and Huszagh (1995) developed a stages model using Uppsala Model to describe the stages of internationalization of franchising companies from the US in four stages: domestic, experimental, active, and committed to internationalization.

According to Merrilees (2014), Phase 3 dates from after 2000, and the authors selected six papers: Quinn and Alexander (2002),
Doherty and Alexander (2004), Altinay and Miles (2006), Cheng, Lin, Tu and Wu (2007), Aliouche and Schlentrich (2011), and Jell-Ojobor and Windsperger (2013). Quinn and Alexander (2002) emphasized the retailing context by reconciling domestic or international franchising choices. They developed a two-by-two matrix model with domestic (franchise or not) and international options (franchise or not).

Doherty and Alexander (2004) emphasized franchisor-franchisee relationships in the international franchising context. The relationships were based on trust, communication, and support, rather than on contract.

Altinay and Miles (2006) analyzed stakeholder issues using the stakeholder theory to provide a frame of reference to examine the decision-making processes involved in international franchising agreements.

Cheng et al. (2007) developed a five-stage model of international franchise expansion and created a conceptual model that described the process theory of international franchising.

Aliouche and Schlentrich (2011) developed a quantitative study of 143 countries with an emphasis on risk and opportunity tradeoffs based on determining the optimal decision.

Jell-Ojobor and Windsperger (2013) developed an integrative framework that investigated the determinants of international franchising governance models by combining organizational economic and strategic management perspectives. This topic is an important subject that requires more attention from researchers.

\subsection{International franchising in Brazil}

In Brazil, according to Marques, Merlo and Luchesi (2005), the motivations for the internationalizing of franchises were similar to those for retail internationalization: the search for new markets, higher sales and profits, greater brand recognition, preventing the entrance of competitors into the domestic market and gains generated by economies of scale. 
According to Khauaja (2010), another aspect to be considered in the internationalization of franchises is the valuation of the brand.

Silva, Mendes and Gomes (2002) analyzed the effects of the internationalization process on the management control of Bob's fast-food franchise. Carvalho (2000) studied the patterns in the supply of franchises internationalization processes, identifying why, where and how they internationalize and focusing on foreign companies that have settled in Brazil, using institutional data for scientific information in the period of 1997-2006. In contrast, there were several factors that discouraged Brazilian franchise expansion into new markets abroad.

Rocha, Borini and Spers (2010) stated that the large size of the Brazilian market is the main barrier to franchise internationalization because they considered the domestic market to be the priority.

According to Mendelsohn (1994), the four most common entry modes used by franchise firms are: 1 . wholly-owned subsidiaries; 2 . master franchising; 3. direct franchising; and, 4. joint venture franchising.

Borini, Rocha and Spers (2012) explained that some franchisors in Brazil allowed only partners to open units abroad, which would likely not succeed. It must be a process with more planning from Brazilian entrepreneurs. When a partner is chosen without a proper structure to develop the brand in different markets, the likelihood of successfully internationalizing a brand is poor (Borini, Rocha, \& Spers, 2012).

Moreover, brand development abroad is more important for franchises in higher stages of internationalization.

\subsection{Internationalization stages}

The internationalization strategy became part of the agenda of American franchises in the 1990s. According to McIntyre and Huszagh (1995): 'in the ' 90 s, only $20 \%$ of American franchises operated abroad. Until then, the focus was on the growth in the American domestic market and developing the domestic franchising mechanisms as a major concern'. The franchising mechanisms represent aspects related to the sustainability of the business, in particular: franchisee support; brand development; increased control capacity; and unit monitoring; among others.

Cavusgil and Nevin (1980) developed a model that described the path followed by North American companies at the time of internationalization via exporting. They used four stages as proposed by the Uppsala Model: nonregular export activities, export via independent representation, sales subsidiary and production, (Johanson \& Vahlne, 1977).

McIntyre and Huszagh (1995) adjusted this framework considering the reality of North American franchises in their internationalization stages, as shown in the first column of Table 2.

Table 2 outlines the four stages of the internationalization process and identifies critical activities. In the domestic franchising stage, operations provide an opportunity to test the franchising mix, and if international operations are required, control, monitoring, support and branding skills will be more intensely demanded (Mcintyre \& Huszgh, 1995).

According to Rocha et al. (2014), 95.8\% of Brazilian franchises (2,376 companies) were in this stage in December 2013, in which the major concerns of the franchises are to grow in the country and to consolidate their positions in the local market.

In stage 2 with experimental involvement, a company has one or a few units abroad, low financial commitment and a small number of lines of business. In general, the main idea is to test the international market and product acceptance.

According to Rocha et al. (2104), 2.1\% of Brazilian franchises (51 companies) were in this stage in 2013, with activities in one or two countries abroad. At that time, the companies were selecting countries and partners and starting operations abroad. 
Table 2

\section{Stages followed during franchise internationalization in Brazil}

Stage 1 - Domestic Franchising:

Franchising solely in the home market

Stage 2 - Experimental involvement:

Preliminary evolution of international expansion, leading to minimal involvement

Stage 3 - Active involvement:

Systematic exploration of expanding international franchising activity

Stage 4 - Committed involvement:

Long-term commitment to franchising

in international markets
$95.8 \%$

2,376 Brazilian Franchises

$2.1 \%$

51 Brazilian Franchises

$1.3 \%$

32 Brazilian Franchises

$0.9 \%$

22 Brazilian Franchises

Note. Source "Estágios da internacionalização das franquias brasileiras", by T. Rocha et al., 2014. Theory proposed from "Internationalization of franchise systems", by F. S. McIntyre and S. M. Huszagh, 1995, Journal of International Marketing, 3, p. 41 based on "A conceptualization of the initial involvement in international marketing, by S. T. Cavusgil and J. R. Nevil, 1980, p. 68-71, with Brazilian data.

In stage 3 with active involvement abroad, the companies experienced international growth. In this active stage, most franchises expanded their operations at a constant, slow pace to meet the legal and managerial requirements of every new market. In general, these companies tended to seek international markets with psychic and cultural similarities to reduce risks and increase the likelihood of success of their business operations (Mcintyre \& Huszgh, 1995).

According to Rocha et al. (2014), there were 32 companies, $1.3 \%$ of the total in 2013, with active involvement, with operations in three or four countries abroad. These companies had more developed operations and had to manage standardization of the marketing mix to attain scale.

Stage 4 corresponds to the high level of commitment involvement abroad. In this stage, the companies have been through the previous stages and have the financial and managerial skills to grow internationally. The investments made abroad are of major importance and show commitment to maintaining and expanding the business abroad (Mcintyre \& Huszgh, 1995).

According to Rocha et al. (2014), there were 22 companies, $0.9 \%$ of the total in 2013 , in the commitment involvement stage working in five or more countries. These companies had to deal with more complex operations and to develop marketing strategies that were more global.

\subsection{The global marketing strategy}

International marketing strategy should be regarded as a part of a larger strategy that is defined by companies and is called the Global Marketing Strategy, or GMS.

A review of the GMS concept reveals three main perspectives: the standardization perspective, the activity coordination perspective, and the integration perspective, as presented in Table 3.

The GMS, from the perspective of standardization, was detailed by Jain (1989), based on Levitt (1983). According to these authors, there is convergence of global cultures with more similar demands and reduction of trade barriers and technological advancements, which causes companies to operate with more globalized orientations. In this situation, standardization normally occurs in the traditional marketing mix: price, product, promotion and place.

A second perspective of the GMS focuses on the configuration and coordination of company value chain activities, as proposed by Craig and Douglas (2000), Porter (1991), and Schweiger and Morrison (1991). Based on this perspective, the GMS is a means to explore existing synergies between different countries and the benefits associated with the country of origin. The configuration of value chain activities is concentrated in a few countries where these activities can be performed more efficiently and with greater synergy. 
Table 3

Major perspectives of Global Marketing Strategy (GMS)

\begin{tabular}{|c|c|c|c|}
\hline Perspective/Main Authors & Comparative Advantage & Key Variables & Effects \\
\hline $\begin{array}{l}\text { Standardization } \\
\text { perspective } \\
\text { Authors: } \\
\text { Levitt (1983) } \\
\text { Jain (1989) }\end{array}$ & $\begin{array}{l}\text { - Economies of scale } \\
\text { - Low cost } \\
\text { - Simplification }\end{array}$ & $\begin{array}{l}\text { - Product standard } \\
\text { - Promotion standard } \\
\text { - Standardized channel structure } \\
\text { - Standardized price }\end{array}$ & $\begin{array}{l}\text { - Increased efficiency } \\
\text { - Consistent global operations } \\
\text { - Knowledge transfer inside } \\
\text { company }\end{array}$ \\
\hline $\begin{array}{l}\text { Configuration coordination } \\
\text { perspective } \\
\text { Craig and Douglas (2000); Porter } \\
\text { (1991); Roth, Schweiger and } \\
\text { Morrison (1991) }\end{array}$ & $\begin{array}{l}\text { - Comparative } \\
\text { advantage } \\
\text { - Interdependency } \\
\text { - Specialization }\end{array}$ & $\begin{array}{l}\text { - Concentration of } \\
\text { value-chain } \\
\text { activities } \\
\text { - Coordination of value chain } \\
\text { activities }\end{array}$ & $\begin{array}{l}\text { - Increased efficiency } \\
\text { - Synergies }\end{array}$ \\
\hline $\begin{array}{l}\text { Integration perspective } \\
\text { Authors: } \\
\text { Birkinshaw and Morrison (1995) } \\
\text { Yip (1995) } \\
\text { Zou and Cavusgil (1996) }\end{array}$ & $\begin{array}{l}\text { - Integrated production in } \\
\text { subsidiaries } \\
\text { - Rationalization } \\
\text { - Global competitive } \\
\text { environment }\end{array}$ & $\begin{array}{l}\text { - Global movement integration } \\
\text { - Global market participation }\end{array}$ & $\begin{array}{l}\text { - Increased efficiency } \\
\text { - Integration as an } \\
\text { international strength }\end{array}$ \\
\hline
\end{tabular}

Note. Source "The GMS: A broad conceptualization of global marketing strategy and its effect on firm performance", by S. Zou and S. T. Cavusgil, 2002, Journal of Marketing, 66, p. 41.

The third GMS perspective is based on integration. According to this vision, the key to the success of a company, on the global scale, is to gain competitive strength through the integration of its activities, as proposed by Birkinshaw and Morrison (1995), Yip (1995), and Zou and
Cavusgil (1996). In a global industry, operations in different countries are interdependent.

Zou and Cavusgil (2002) proposed a combination of these three perspectives in a single model to measure the global marketing strategy of a company, as shown in Figure 1.

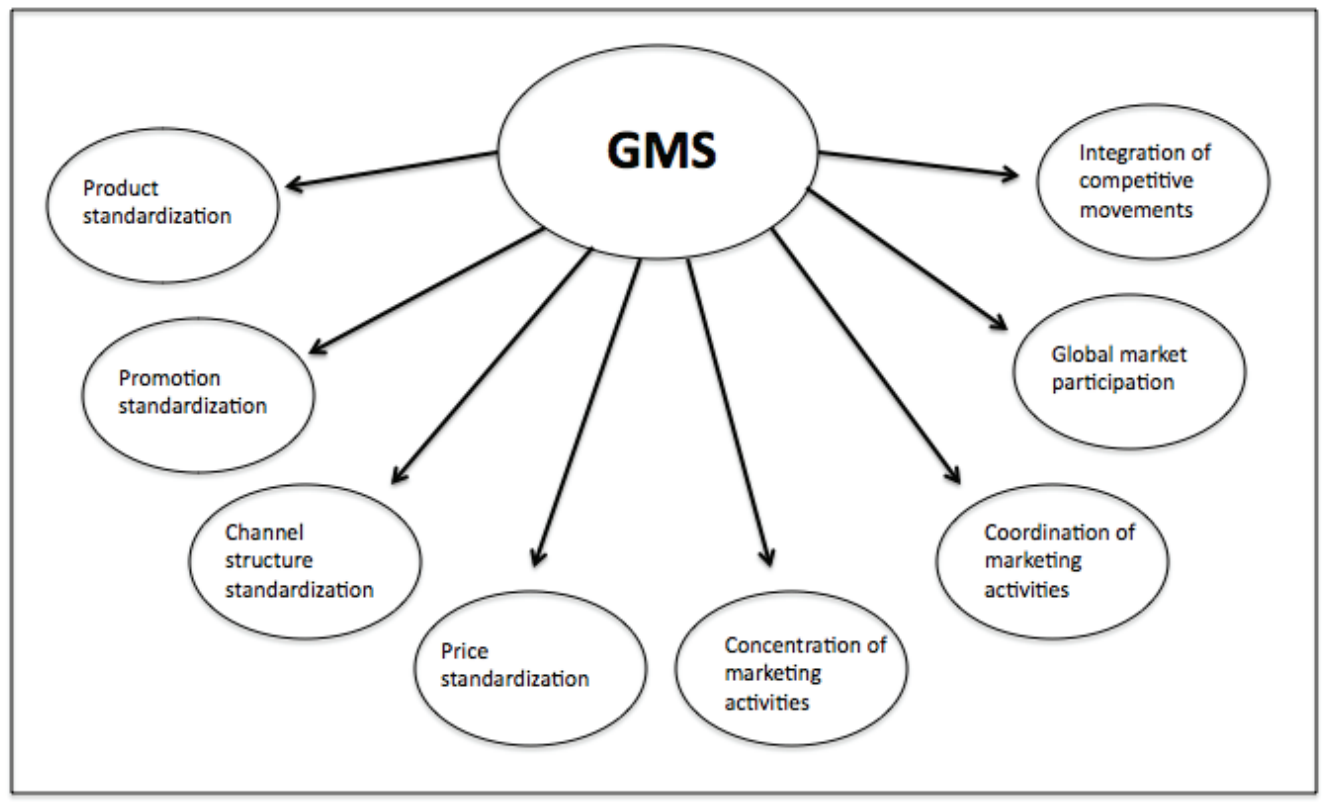

Figure 1. Overview of the Global Marketing Strategy (GMS)

Source: "The GMS: A broad conceptualization of global marketing strategy and its effect on firm performance”, by S. Zou and S. T. Cavusgil, 2002, Journal of Marketing, 66, p. 43. 
In Figure 1, to measure GMS, a company must consider a series of decisions at the headquarters that include product, promotion, placement and price standardization. Additionally, concentration and coordination of marketing activities must be planned at this level, which would allow for the measuring of market participation and inferring about competitive actions. Other decisions involve global thinking derived from activities worldwide and their subsequent integration.

According to Cavusgil, Knight, and Riesenberger (2010), the GMS is highly complex due to local competitors and cultural differences related to language, living standards, regulations, financial conditions and the quality of the business infrastructure. In contrast, the GMS allows the monitoring of global competitors and improvements of the company value chain by means of its activities in each market.

Douglas and Craig (2011) explained that the use of a type of GMS varies according to the industry. Globally competitive industries, such as the fashion industry, the luxury industry, and the microprocessor industry, can sell the same product worldwide. However, there are other industries to which standardization does not apply. The authors created the label 'semi-global marketing strategy' for companies that are involved in following different directions in different parts of the world, resulting in greater autonomy at the local level.

For Cavusgil et al. (2010), the main challenge in GMS is to establish a balance between standardizing marketing elements and the adapting of these elements to different international markets. These authors suggest that standardization is more common in industries that already conduct business globally because their products are similar in several markets, and their marketing approach is standardized. Communication is apparently the item of the marketing mix program that can combine a potential level of standardization with the necessary level of adaptation to each country (Oliveira \& Crescitelli, 2008).
Rocha and Silva (2011) used the GMS model to analyze how the level of autonomy displayed by subsidiaries in Brazil influences the marketing-mix program. In a case study developed in an American multinational from the food sector, the firm's brands were very important to this firm's success overseas, and the brand policies were defined carefully at two levels: subsidiaries and headquarters. This brand policy directly influenced the autonomy to innovate in marketing at the subsidiaries level. They argued that the managers at subsidiaries needed to understand the importance of global marketing strategies and also identified the circumstances in which autonomy pays off.

When we observe the reality of Brazilian franchise companies through the lens of the GMS framework, we obtain the proposition that not all of the dimensions proposed by the authors were equal. This fact will be analyzed in the empirical section of this article.

\section{Propositions}

Our propositions have been formulated to examine the use of GMS in different stages of internationalization in the franchising sector.

We believe that companies with greater development of their foreign operations will use more GMS items than companies in earlier stages.

Marketing program standardization has been linked to the centralization of marketing decisions for a long time (Doz \& Prahalad, 1980; Jain, 1989) because the implementation of a standardized strategy requires strong control and coordination between headquarters and subsidiaries.

Franchises that implement standardized marketing programs want to protect and defend their product formulations, brand names, packaging, pricing, and other marketing mix elements by tightly centralizing decision making to control positioning in the local market (Özsomer \& Simonin, 2004).

P1: Franchises in the stage of active involvement abroad will use a marketing 
strategy more associated with standardization of the marketing mix, related to decisions about products, communications, prices and distribution.

In contrast, companies with more complex operations abroad in stage 4 - committed involvement, present in more than five countries, will need to be concerned with other issues, such as the concentration of marketing activities, coordination of these activities in different countries, and integration of the results of these operations into market share.

Therefore, we developed the second preposition.

P2: Franchises in the stage of committed involvement abroad will use GMS with decisions about products, communications, price and distribution standardization, marketing activity concentration, and the coordination and measurement of market participation.

\section{Methodology design}

This section describes the adopted empirical research method and procedures for ensuring the reproducibility of this study.

The case study was complied with the protocol suggested by Yin (2015), with the objectives, main questions and case study selections stated.

\section{I Case study protocol - An overview of the research}

The aim of the study was to identify the strategies used by the marketing departments of franchises in different stages of internationalization processes. In addition, we intended to determine the decisions that were made by marketing managers as their GMS and their influences after the process of internationalization. The authors were responsible for the research.

\subsection{Field procedures}

a) Methodological aspects:

To encapsulate a phenomenon in which contextualization was necessary, we used a qualitative approach. We decided to conduct exploratory research with the multiple case study method to explore the data.

According to Toledo and Shiriashi (2009), the choice of a case study can provide opportunities for data collection, granting the researchers access to information that would not be accessed by other methods.

b) Criteria for selecting the cases:

The first criterion analyzed the most internationalized companies from Brazil in the 2011 Internationalization of Brazilian Franchises in Ranking FDC (Fundação Dom Cabral [FDC], 2011). The first company in these rankings, present at that time in 20 countries, was considered to be the most important case to represent the stage of committed involvement. It is a company from the footwear and apparel sector, representative of a Brazilian franchise with a strong operation abroad and with a more complex marketing operation, making it significant to study the GMS model.

The second criterion for selecting the other cases was to remain in the footwear and apparel sector because it is part of the fashion industry, which is a sector indicated by Cavusgil et al. (2010) to be a globalized industry. It is a very active sector in Brazil.

The third criterion for selecting the other cases was to look in Rocha et al. (2010) for other companies in footwear and apparel.

We found eight more companies from the same sector. We selected companies that have been internationalized for more than 7 years in three or four countries abroad with active involvement. We attempted to contact these companies, and four of them agreed to participate in our research. In the final version, one company did not allow us to use the case, so we finished with three cases, which we present anonymously in Table 4: Case A, Case B, and Case C. 
Table 4

\section{Case information}

\begin{tabular}{|c|c|}
\hline $\begin{array}{l}\text { Case A - } \\
\text { Active } \\
\text { Involvement }\end{array}$ & $\begin{array}{l}\text { The company was founded in } 1996 \text { by an entrepreneur who opened a small stand to sell glasses with different designs } \\
\text { following fashion trends. In 1997, the company opened its first shop, and in less than one year, it opened more than } \\
20 \text { new points of sale. The first stand in a shopping centre was installed in Sao Paulo in 2000. In 2005, the company } \\
\text { opened a store in Portugal. By 2012, the franchise chain had more than } 400 \text { points of sale in Brazil, the US, Portugal, } \\
\text { Angola and Colombia. }\end{array}$ \\
\hline $\begin{array}{l}\text { Case B } \\
\text { - Active } \\
\text { Involvement }\end{array}$ & $\begin{array}{l}\text { The company was created in } 1979 \text { as a small operation for the retail selling of jewellery. In 2001, the company was } \\
\text { transformed to operate in the franchise format in the jewellery sector. The first foreign country to host the brand was } \\
\text { the US. After market research, the brand was launched in Portugal. By 2012, the brand had three shops in Portugal - } \\
\text { two franchisor-owned shops and one with a local partner - and operations in the US and Colombia. }\end{array}$ \\
\hline $\begin{array}{l}\text { Case } \mathrm{C}- \\
\text { Commitment } \\
\text { Involvement }\end{array}$ & $\begin{array}{l}\text { The company was founded in } 1991 \text { in Rio Grande do Sul as a manufacturer of leather products. In } 1993 \text {, the brand } \\
\text { was sold in multi-brand stores and started to export to Argentina. In 2004, it expanded through the franchise system. } \\
\text { The aim of the company, as a global brand, is to manufacture quality products according to international standards } \\
\text { and to provide customized services. By 2012, it had more than } 270 \text { exclusive shops in } 20 \text { countries. }\end{array}$ \\
\hline
\end{tabular}

Note. Web sites of Companies A, B, and C.

c) Analysis units: Marketing strategy and marketing activities in the internationalization process

\section{d) Sources: Semi-structured interviews} were conducted by the authors with two executives in each company, responsible for:

Case A - The Director of Business Development and the Marketing Manager;

Case B - The Director of Retail and the Marketing Manager; and

Case C - The Director of Expansion and the Marketing Manager.

The in-depth interviews were conducted in October and November 2011.

\section{e) Data collection:}

Several sources of information were used (reports, press releases, news, interviews and the authors' observations of the facts) to enrich the study and to guarantee the quality of the conclusions. Other data was also collected from Web sites and from news published about the companies.

The script of each interview was divided into three blocks. The subjects were established based on the theoretical basis and the objectives of the study, as presented in Table 5.

Table 5

Topics of questions to be answered and sources of evidence

\begin{tabular}{ll}
\hline Question topic & Data sources \\
\hline Company background and its trajectory until 2012 & Interviews, company Web sites, news \\
\hline $\begin{array}{l}\text { The company internationalization process: } \\
\text { Motivations, barriers, how countries are selected, entry mode, stage of } \\
\text { internationalization }\end{array}$ & Interviews, documents, developed actions and planning \\
\hline
\end{tabular}

Global marketing strategies adopted by the company:

Adaptation of price, product, promotion and place

Concentration of marketing activities

Management and coordination of marketing activities Interviews, published documents about the company

Integration of marketing activities

Global market participation

Assessment of marketing results

The first block, in Table 5, concerned the company history from its creation through 2012, and we used secondary data. The second block was related to the internationalization process, and 
we asked the person in charge. The third block referred to GMS.

The thematic blocks were validated and discussed with two academic experts who had knowledge of the concepts used.

\subsection{Data analysis plan and case study report}

a) Data: All of the interviews were recorded and transcribed.

b) Content analysis: All of the data was analyzed using Atlas.ti software to store the collected data, following the content analysis technique proposed by Krippendorff (2004) and Bardin (2007).

c) Categories: We had two main categories: internationalization and global marketing strategy. Then, the data was targeted, according to the subcategories established, to group one: motivations to internationalize; barriers to internationalization; factors facilitating internationalization; the country selection criteria; franchise management abroad; country facilities; and gradualism in the process of internationalization; and to the second group: brand management; product standardization; price standardization; distribution channel of standardization; promotion; coordination and concentration of marketing activities; participation in the global market; and integration of competitive movement.

The main criterion for the category analysis was semantic, and a conceptual map was developed considering the most relevant subcategories. The conceptual map of each company showed the strongest links of subcategories in each case.

The cases are presented according to their history, internationalization and marketing strategies and the local situation. We cannot generalize to other cases, confirming the argument of Stake (2013) that a case study is an investigation file of the case inquiry.

\section{Results}

This section provides an overview of the cases and a discussion of the results according to the theory.

\section{I Case $A$ - active involvement}

In 2005, company A opened its first store with a franchisee in Lisbon, Portugal. In the same year, it opened an owned store in Los Angeles.

In 2012, the company had an operation in Portugal with five stores, the United States with two stores, and Angola with one store. It was in the stage of active involvement abroad, with operations in three countries. In 2012, the company had more than 400 points of sale in total, including in Brazil, the US, Portugal, Angola and Colombia.

The company adopted the same strategic positioning in all of its business markets. Most of its production came from Asia.

The company centralizes its purchases in Brazil, and the overseas franchisees place orders at the head office. The basic products mix that is purchased by the international franchisees is chosen by the Brazilian office.

After internationalization, the former department of products and imports was transformed into the department of imports and exports.

During the implementation of new overseas franchise units, a Brazilian manager was sent abroad to help the local franchisee to establish the shop and to identify opportunities and risks. This person also served as a direct channel of communication between the Brazilian office and the international franchisee.

In 2012, an international manager was hired to oversee market expansion and to maintain the support system offered to overseas franchisees. The internationalization process includes the assessment of opportunities, not only to internationalize the brand but also to develop further the brand management in foreign countries.

The company follows a polycentric orientation, which means that the decisions about the marketing mix are managed by the Brazilian head office, although the company recognizes that local cultural differences have significant influences on the market. 
Franchisees in foreign countries and in Brazil actively participate in the creation process, and they suggest models and adaptations by means of software developed for the company in the creations department.

The interviews conducted in Case A were coded, and this data was used to create Table 6 , with two main categories - Internationalization and Global Marketing - and the subcategories that emerged in the field. The numbers shown in Table 6 are repetitions and indicate the number of times that these subcategories were mentioned by the interviewee.

Table 6

Categories and subcategories - Case $\mathrm{A}$

\begin{tabular}{lcl}
\hline Category & Repetitions & Subcategories \\
\hline & 5 & brand management; \\
& 4 & overseas franchise management; \\
3 & gradualism; \\
Internationalization & 2 & networks; \\
& 2 & factors that facilitate internationalization; \\
& 1 & criteria for choosing the destination country; \\
& 1 & reasons for internationalization. \\
\hline & 4 & product standardization; \\
Global Marketing & 3 & promotion standardization; \\
& 2 & price standardization; \\
& 1 & channel structure standardization; \\
& 1 & coordination of marketing activities; \\
& 1 & concentration of marketing activities. \\
\hline
\end{tabular}

The concept map (see Figure 2) shows the links and the relationships between the analysis categories. The subcategory with the most repetitions in the interviews with executives from Case A was brand management, including product standardization, promotion standardization and price standardization. The continuous lines represent stronger links, and the dotted lines represent weaker links.

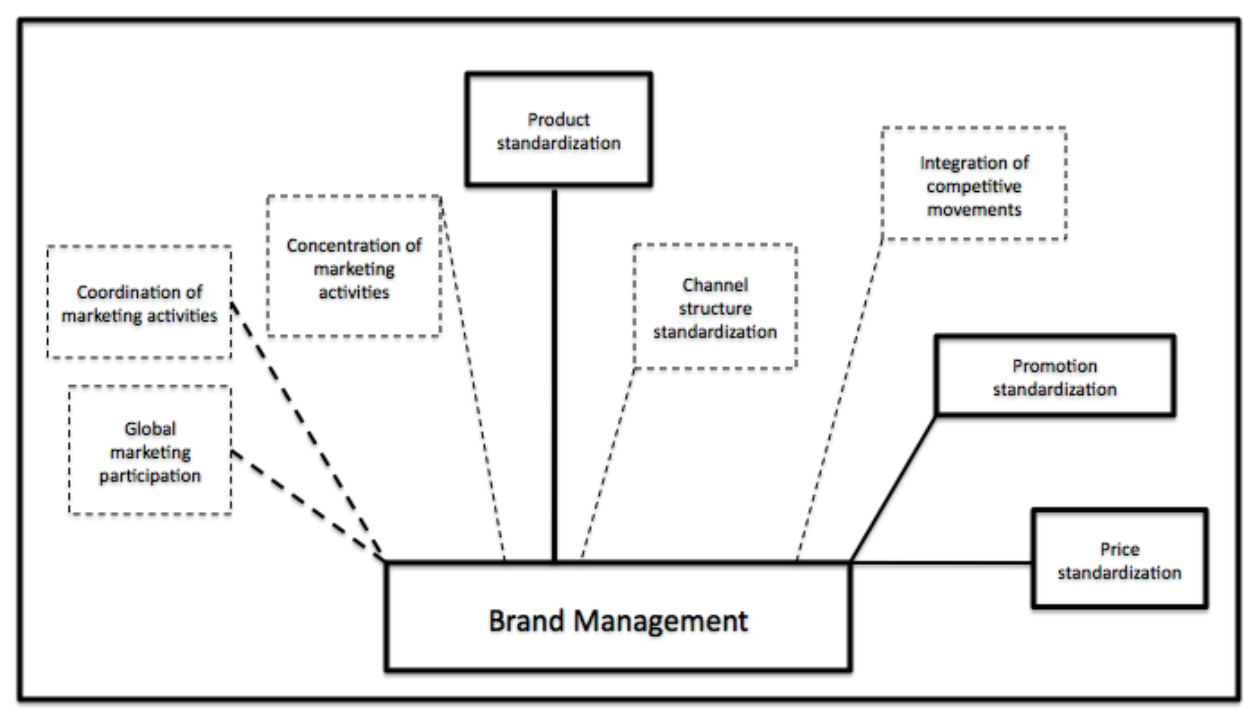

Figure 2. Concept map - Case A 
It was also evident in the interviews that company A has concerns about how to select and manage overseas franchises, either through associations and partnerships or through a master franchisee. These concerns are part of the active involvement process, when companies have managed the operation abroad with slow growth step by step. There were worries about how to expand the internationalization process while maintaining the same brand positioning abroad.

\subsection{Case B - active involvement}

In 2004, company B entered a partnership with one of the largest department stores on the Iberian Peninsula in Spain. The company exported 10 thousand pieces to this chain, but later, it decided to continue growing only locally and closed the international operation.

In 2006, the company opened a store in the Soho neighbourhood in New York with a local franchisee and an owned store in Los Angeles, administered by the family. After the economic crisis in 2008, it closed its store in New York, and they kept the one in L.A.

In 2012, there were three stores in Portugal: two owned and one franchisee. In addition, they have units in the US and Colombia. The company is in stage 3 - active involvement with the internationalization process, with presence in three countries.

According to one of the interviewees, $70 \%$ of the pieces are manufactured in Asia, and only $30 \%$ are made in Brazil. The products that demand more technology are manufactured in Asia, and the remainder are made in Brazil and exported to units abroad.

Regarding products with a strong craftsmanship emphasis, the company has a backup of Brazilian suppliers that are "well accepted in the external market", according to one of the interviewees.

Company B had a department that was responsible for international business or "the new business and new markets incubator". Franchisee training was a constant concern of the company, which believes that all franchisees should have entrepreneurial characteristics to run units.

When questioned about the decision to standardize or adapt products, one of the executives stated that the company had already undergone some cycles, and the current issue is brand. According to the interviewee, "there is a $20 \%$ to $30 \%$ margin of adaptable products, which will not uncharacterize the brand's identity and will help in the empathy adjustment process with the local market".

The company has an agency that is responsible for the communication platform, and part of this advertising communication is adapted because the message must be received and interpreted in the same manner in different countries. The interviewee also stated that international franchisees have a direct channel to the senior manager.

In terms of price standardization, the target public in Brazil is classes A and B, while in foreign countries, the brand targets classes $\mathrm{B}$ and C. "Today, classes A and B in foreign countries still use jewellery as an accessory, which does not occur in Brazil due to the violence to which we are constantly exposed", says one of the executives to justify the different positioning between the countries.

The interviews were also coded using Atlas. ti software. The results were used to create Table 7, which shows the categories and subcategories recognized in the interviews.

In Table 7, regarding internationalization, overseas franchise management was the main topic, and regarding GMS, the company expressed concern about promotion standardization, product standardization and coordination of marketing activities, as shown.

The concept map (Figure 3) shows the links and the relationships between the analysis categories. The subcategory with the most repetitions was overseas franchise management, which has strong links with promotion standardization, product standardization and coordination of marketing activities. 
Table 7

Categories and subcategories - Case $B$

\begin{tabular}{lcl}
\hline Category & Repetitions & Subcategories \\
\hline & 11 & overseas franchise management; \\
& 7 & reasons for internationalization; \\
Internationalization & 5 & criteria for choosing the destination country; \\
& 2 & factors that facilitate internationalization; \\
2 & facilities of the emerging country; \\
& 1 & barriers to internationalization. \\
\hline & 8 & promotion standardization; \\
Global Marketing & 6 & product standardization; \\
& 4 & coordination of marketing activities; \\
& 2 & price standardization; \\
& 2 & integration of competitive movements; \\
& 1 & global market participation. \\
\hline
\end{tabular}

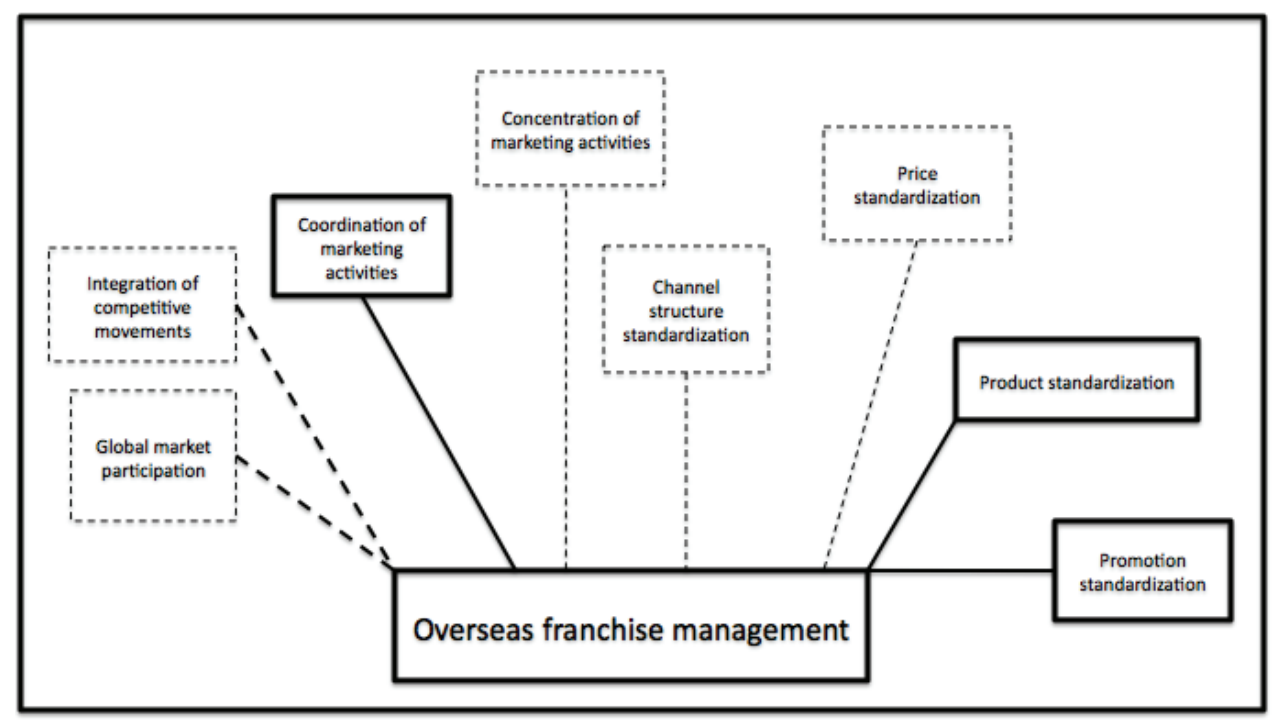

Figure 3. Concept map - Case B

Regarding promotion standardization, the company adopts a polycentric vision by identifying different needs and making adaptations to address these needs. Product standardization remains a concern. Price standardization fluctuates with cultural issues, and it is related to brand positioning, distribution, demand and supply.

The subcategory of gradualism in the internationalization process was the most repeated one. This subcategory was evidently present in the company's internationalization process because it is still an issue to select franchisees overseas as the internationalization process is gradual.
This fact is characteristic of the active involvement stage, in which, according to Carneiro and Dib (2007), as companies acquire a more adequate level of knowledge of the new market, the level of commitment of resources also increases.

\subsection{Case $\mathrm{C}$ - commitment involvement}

In 2012, company $C$ had more than 270 stores, 158 of which were in Brazil and 112 abroad; they have a strong operation in more than 20 countries, showing commitment involvement. 
In 1993, company C started its overseas operations through multi-brand shops and by exporting products to Argentina. In 2004, company $\mathrm{C}$ expanded in the form of a franchise, and it opened its first franchise in Chile. In 2009 and 2010, the company received the Franchising Seal of Excellence from the ABF and the International Business Award Franchise for 2009 in France. In 2012, its products were sold in more than 100 countries in five continents. Its vision was "to be a global brand company", and the mission statement was "to develop a value brand".

One executive explained that 'the company internationalization process emerged naturally. Many shops were already selling our products, and the migration to franchising was a consequence. When we saw the potential, we included this internationalization opportunity in our strategic planning'. Regarding country decisions, company C took the opportunity to choose a place where it already sold through a multi-brand channel and had partners.

Case C has 25 overseas employees responsible for transmitting information and ensuring the best practices for the shops, which, according to the interviewee, "cannot always be applied in Brazil". They work in markets with different characteristics, and they attempt to maintain the brand and the quality of the operation.

The interviews were again coded using Atlas.ti software. The results are displayed in Table 8 , with the categories and subcategories for Case C.

\section{Table 8}

\section{Most frequent analysis subcategories}

\begin{tabular}{lcl}
\hline Category & Repetitions & Subcategories \\
\hline & 4 & brand management; \\
3 & overseas franchise management; \\
Internationalization & 2 & barriers to internationalization; \\
& 1 & criteria for choosing the destination country; \\
& 1 & facilities of the emerging country; \\
& 1 & reasons for internationalization. \\
\hline & 5 & integration of competitive movements; \\
Global Marketing & 4 & coordination of marketing activities; \\
& 3 & promotion standardization; \\
& 2 & price standardization; \\
& 2 & product standardization; \\
& 1 & channel structure standardization; \\
& 1 & concentration of marketing activities. \\
\hline
\end{tabular}

Table 8 shows that the most repeated item in the interviews with executives from Case $\mathrm{C}$ about internationalization process was brand management. Further, unlike the other cases and due to the complexity of the operations in Case $\mathrm{C}$, integration of competitive movements and concerns about coordinating marketing activities were the most frequent subcategories.

In the concept map (Figure 4), brand management has a strong link with integration of competitive movements, coordinating of marketing activities and promotion standardization. Product standardization, despite not being mentioned by the executives, is consolidated in standardization, and there is no product adaptation.

In terms of promotion standardization, the company adopts a polycentric vision because it identifies the different needs of the countries in which it operates, such as adjusting the language and adaptation. The coordination of marketing activities is a challenge for the company because this coordination must ensure brand positioning in several countries. 


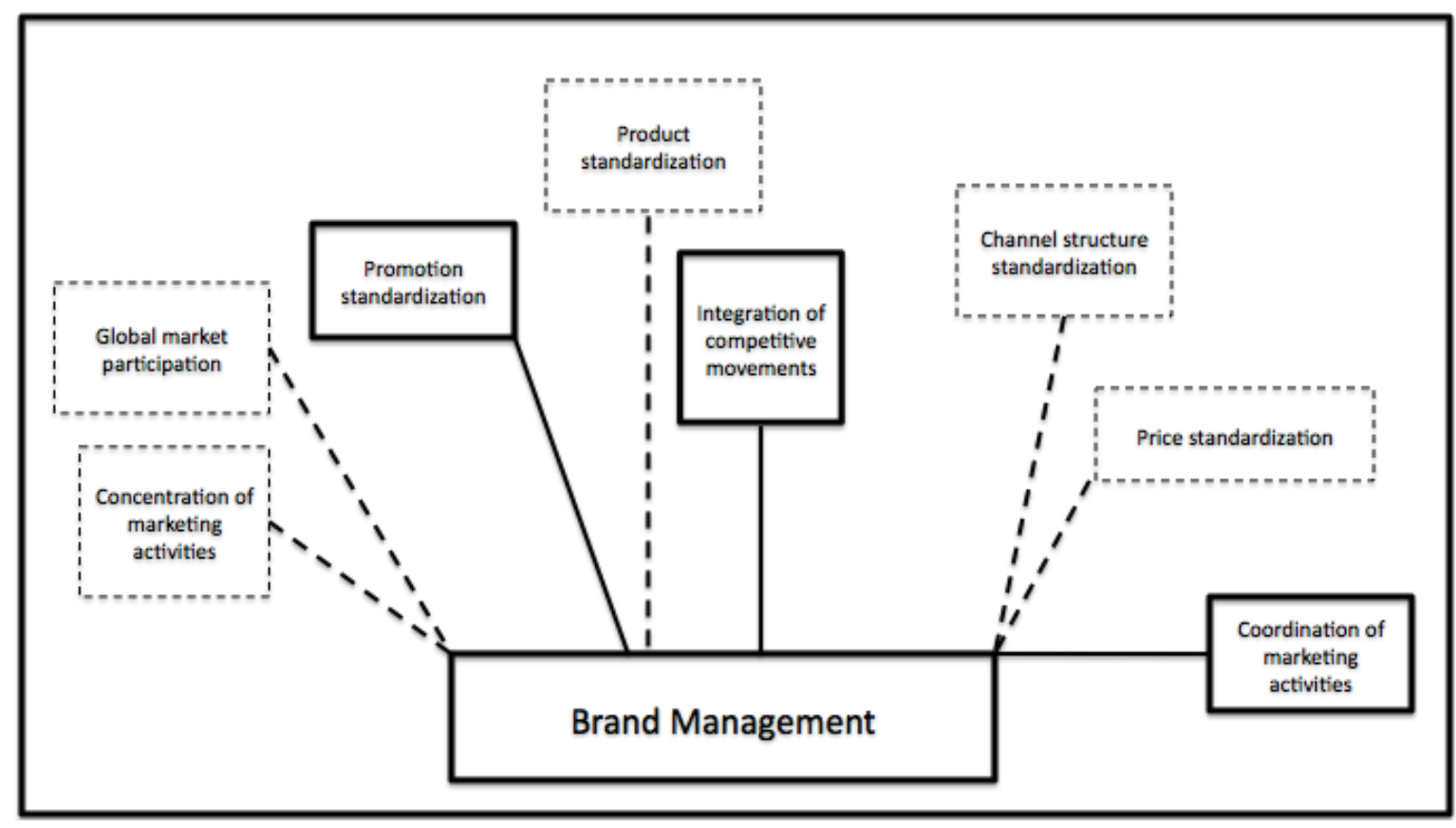

Figure 4. Concept map - Case C

In case $\mathrm{C}$, with a commitment to involvement abroad, the role of the company's marketing manager is to manage the global brand, define its strategy and develop the programs that must be executed locally. The integration of competitive movements reflects the company's concern about the interdependence of marketing activities in different countries.

In case $\mathrm{C}$, with commitment to involvement, the coordination of marketing activities and brand management are the most important issues in the internationalization process.

\section{4 Comparative case analysis}

In the three cases, the manners in which the internationalization process was conducted indicate that there was gradual entry due to uncertainties regarding the new markets, which confirms the theory proposed by Johanson and Vahle (1977), McIntyre and Huszagh (1995), Vahle and Johanson (2013), and Rocha et al. (2014).

Case A and Case B started operations abroad in 2005 and 2004, respectively, almost eleven years ago, and they are growing with active involvement, showing that time is an important issue in gradual development, and the speed of growth depends on the results of the operation abroad, as explained by McIntyre and Huszagh (1995) regarding active involvement.

Case A and Case B are retailers that manufacture their products in China, and they started the internationalization process because a partner wanted to open a store abroad or wanted to sell their products abroad. It was a reactive process, as explained by Doerthy (2009) and Rocha et al. (2012). This start caused the companies to open and close units abroad in the beginning, as presented in both cases, and it is very common in emerging economies.

Case C started as a manufacturer of leather products that started operations abroad in 1993, 22 years ago, by exportation, and since then, it has had operations in twenty countries. This commitment to involvement with international operations has caused the company to consider brand management as an international issue.

Table 9 shows a summary of the results in terms of eight GMS dimensions. In the stage of active involvement, the dimension of product adaptation is an important issue, and case $\mathrm{A}$ adapts $30 \%$, while case $\mathrm{B}$ adapts $10 \%$, different from case $\mathrm{C}$, which has commitment to involvement 
and does not make product adaptations. If one considers that they are in twenty countries, not adapting its products has provided scale efficiency and scope gains, which is different from active involvement, with greater adaptation to serve three or four countries.
In all of the cases, depending on the stage, the companies undertook promotion (communication) adaptation, which is associated with language and cultural differences.

\section{Table 9}

\section{Results of the analyzed companies relative to the eight GMS dimensions}

\begin{tabular}{llll}
\hline Stage & Active Involvement & Commitment \\
\hline GMS & Case A & Case B & Case C \\
\hline Product standardization & Adapted 10\% & Adapted 30\% & Not adapted \\
\hline $\begin{array}{l}\text { Promotion standardization } \\
\text { Price standardization }\end{array}$ & $\begin{array}{l}\text { Adacally adapted with an } \\
\text { positioning }\end{array}$ & $\begin{array}{l}\text { Locally adapted with an } \\
\text { advertising agency }\end{array}$ & $\begin{array}{l}\text { Locally adapted with an advertising } \\
\text { agency }\end{array}$ \\
\hline $\begin{array}{l}\text { Channel structure } \\
\text { standardization }\end{array}$ & Adapted & $\begin{array}{l}\text { Adapted according to } \\
\text { positioning }\end{array}$ & $\begin{array}{l}\text { Adapted according to positioning and } \\
\text { demand }\end{array}$ \\
\hline $\begin{array}{l}\text { Coordination of marketing } \\
\text { activities }\end{array}$ & Brazil & Adapted & Not adapted \\
\hline $\begin{array}{l}\text { Concentration of marketing } \\
\text { activities }\end{array}$ & Brazil & Brazil & Brazil and local offices in five countries \\
\hline $\begin{array}{l}\text { Integration of competitive } \\
\text { movements }\end{array}$ & not mentioned & Brazil & Brazil \\
\hline \begin{tabular}{l} 
Global market participation \\
\hline
\end{tabular} & not mentioned & not mentioned & Concern about integrating \\
\hline
\end{tabular}

In Table 9, when we analyze the cases and the stage of involvement, we find similarities in case $\mathrm{A}$ and case $\mathrm{B}$.

In case $A$ and case $B$, the firms changed their positioning abroad, and it affected the price. In case $\mathrm{C}$, the price was associated with positioning and the demand of the local market.

In case $A$ and case $B$, with active involvement, channel adaptation is a concern because they must select new partners and open new stores abroad. In a more complex operation, as in case $\mathrm{C}$, the franchise system is already consolidated, and the selection of franchisees is global and planned, and follows pre-established criteria. All the companies have international expansion management.

Regarding the dimension of coordination of marketing activities, with active involvement, cases A and B still concentrate the planning of all of their activities in Brazil.
Case $\mathrm{C}$, in contrast, has offices in Milan, Mexico City, Buenos Aires, Santiago and Lima to coordinate marketing in twenty countries.

Regarding the concentration of marketing activities, the executives of the three companies stated that they use local partners, such as advertising agencies and distribution partners, but that the final decisions are always made in Brazil.

The only company that was concerned about its participation in the global market and the integration of competitive movements was case $\mathrm{C}$, reflecting its size and the number of outlets that it has distributed worldwide in the committed involvement stage.

\section{$5 \cdot 5$ Discussion}

When we think about internationalization processes from emerging markets, we must consider time as a dimension. After twenty years abroad, case C constructed a global company, 
and it was ranked by the FDC (2011) as the most internationalized Brazilian franchise.

It already practices the global marketing strategy proposed by the GMS theory in a more comprehensive manner than the other cases.

Using this case to illustrate, we can confirm P2: "franchises in the stage of committed involvement abroad will use GMS with decisions about products, communications, price and distribution standardization, marketing activity concentration and coordination and measuring of market participation".

In contrast, in the stage of active involvement, Case A and Case B are closer to what the theory calls international marketing strategy (Cavusgil et al., 2010) and not global marketing strategy. In this stage, marketing actions leading to further expansion and decisions about the marketing mix are made at the head office. We can see at this time more product adaptation and channel adaptation than in other stages.

Using this case to illustrate, we can confirm P1: "franchises in the stage of active involvement abroad will use a marketing strategy more associated with standardization of the marketing mix, related to decisions about products, communications, prices and distribution".

With active involvement, according to Douglas and Craig (1989), the focus is on economies of scale, and expansion actions are driven by the opportunism of partners and franchisees.

With active involvement, franchises still choose their target markets mostly through their contact networks, in agreement with the networks approach proposed by Johanson and Mattsson (1988), according which a firm can establish positions in networks with new partners for itself, and it is becoming more important in online business, as stated by Vahle and Johanson (2013).

The internationalization process of emerging markets is a process of resource commitment. Additionally, this process can be perceived as the exploration of potential relationships across borders, with the objective of learning. This process is perceived as incremental, undertaken for the benefit of learning through successive commitment steps (Johanson \& Vahlne, 2006) in an increasing number of foreign markets, rather than being a planned process that is deliberated and based on a rational analysis (Hilal \& Hemais, 2003).

The cases show the importance of the GMS for the internationalization process of emerging markets, such as Brazilian franchises. They are in agreement with Merrilees (2014), who reported that the greatest opportunity for future international franchising research would be to add a branding theory perspective.

\section{Conclusions}

The internationalization of franchises from emerging markets is an important issue, and this paper addressed this subject considering the stages of internationalization and GMS.

In the theoretical review, we realized that each stage has a different type of commitment to the operation abroad. In the initial stages, the company is experimenting with the international environment, and if it is not undertaken in a planned way, the company is more susceptible to failure (Doherty, 2009; Rocha et al., 2012).

In the stage of active involvement, the franchise chain usually has slow growth because it does not have resources and structure, and Case A and Case B required eleven years to become established in three or four countries. The marketing issues that these companies presented are concerns about brand management, marketing mix adaptation and standardization dilemmas. These issues have been studied in theories related to international marketing strategies.

These companies must consider that the greater the degree of product standardization is, the greater the scale efficiency and scope are, and the greater the synergy is throughout the entire chain and the expansion of new product lines is.

In terms of the concentration of marketing activities, this dimension is still the responsibility of the franchisor in Brazil for all of 
the studied franchises. This fact shows that the franchises still plan and coordinate these activities ethnocentrically.

The only franchise that moves in the direction of concentrating these activities outside the country of origin is Case $\mathrm{C}$. The coordination of its marketing activities in different countries occurs with the help of local offices located in some cities around the world.

However, the last four dimensions of the GMS - concentration of marketing activities, coordination of marketing activities, global market participation and integration of competitive movements - are still associated with the stage of commitment involvement. These dimensions become more important as the franchise increases its number of overseas units.

In terms of managerial recommendations, for companies in stages with active involvement, our recommendation is to create more units in the same country before opening them in a new country to create economies of scale. This step facilitates control of the operation and enables a lower cost of adapting products and communication pieces. In this stage, the brand begins to be relevant, and our companies must have a department dedicated to parties abroad.

For companies in stages with commitment involvement, our recommendation is to pay greater attention to brand management abroad, standardization of product mix or service, integration of activities of foreign operations and coordination of the units in an integrated manner. The integration of units increases complexity, leading to a search for a more professional executive team.

The Brazilian franchises can guide their international expansion according to the proposed framework and can identify two main dimensions: International Marketing Strategy (IMS) and Global Marketing Strategy. The International Marketing Strategy includes decisions about the degrees of standardization of products, prices, channel structure and promotions. The GMS includes these dimensions, in addition to concentration and coordination of marketing activities, the integration of competitive movements and participation in the global market.

Franchises can use IMS to guide the development of their marketing mix in a planned and organized manner. Once implemented, franchises can create the structure to operate globally and focus their actions on concentrating and coordinating their marketing activities, increasing their participation in the global market, and pursuing integration of competitive movements to achieve greater synergy among franchise units.

As limitation, this study was a multiple case study, and the results cannot be generalized. However, it represents an attempt to explore the chosen cases in depth.

In terms of future research, we therefore acknowledge the need to establish constructs that would be more amenable to development in a quantitative study in which we can measure the impact of the dimension of GMS on the ability of franchises to grow and succeed. Other studies could analyze brand management, IMS and GMS in a larger number of franchises in different sectors, as well as in different countries.

\section{References}

Aliouche, E. H., \& Schlentrich, U. A. (2011). Towards a strategic model of global franchise expansion. Journal of Retailing, 87(3), 345-365.

Altinay, L., \& Miles, S. (2006). International franchising decision-making: An application of stakeholder theory. The Service Industries Journal, 26(4), 421-436.

Associação Brasileira de Franquias. (2016). Guide franchising Brasil ABF. Retrieved from http:// www.abf.com.br/

ABF. Associação Brasileira de Franquias. (2013). . Retrieved from http://www.abf.com.br/.

Bardin, L. (2007). Análise de conteúdo. Lisboa: Edições 70. 
Birkinshaw, J. M., \& Morrison, A. J. (1995). Configurations of strategy and structure in subsidiaries of multinational corporations. Journal of international business studies, 26(4), 729-753.

Borini, F., Rocha, T., \& Spers, E. (2012). Desafios para a internacionalização das franquias brasileiras: um survey com franquias internacionalizadas. In P. L. R. Melo, \& T. Andreassi (Org.s), Franquias Brasileiras: Estratégia, empreendedorismo, inovação e internacionalização (pp. 71-87). São Paulo: Cengage Learning.

Carneiro, J. M. T., \& Dib, L. A. (2007). Avaliação comparativa do escopo descritivo e explanatório dos principais modelos de internacionalização de empresas. Internext, 2(1), 1-25.

Carvalho, M. (2000). Internacionalização de franquias: Um estudo exploratório no ramo de alimentação (Dissertação de mestrado). Universidade Federal do Rio de Janeiro, Rio de Janeiro, RJ, Brasil.

Cavusgil, S. T., Knight, G., \& Riesenberger, J. R. (2010). Negócios internacionais: Estratégia, gestão e novas realidades. São Paulo: Pearson.

Cavusgil, S. T., \& Nevin, J. R. (1980). A conceptualization of the initial involvement in international marketing. In C. W. Lamb \& P. M. Dunne (Eds.), Theoretical developments in marketing (pp. 68-76). Chicago: American Marketing Association.

Cheng, J. M. S., Lin, J. Y. C., Tu, H. H., \& Wu, N. S. (2007). Toward a stage model of the international franchise system development: The experience of firms from Taiwan. Journal of Marketing Channels, 14(4), 65-83.

Craig, C. S., \& Douglas, S. P. (2000). Building global brands in the 21 st century. Japan and the World Economy, 12(3), 273-283.

Doherty, A. M. (2009). Market and partner selection processes in international retail franchising. Journal of Business Research, 62(3), 528-534.

Doherty, A. M., \& Alexander, N. (2004). Relationship development in international retail franchising: Case study evidence from the UK fashion sector. European Journal of Marketing, 38(9/10), 1215-1235.

Doherty, A. M., \& Quinn, B. (1999). International retail franchising: An agency theory perspective. International Journal of Retail \& Distribution Management, 27(6), 224-237.

Douglas, S. P., \& Craig, C. S. (1989). Evolution of global marketing strategy-scale, scope and synergy. Columbia Journal of World Business, 24(3), 47-59.

Douglas, S. P., \& Craig, C. S. (2011). Convergence and divergence: Developing a semiglobal marketing strategy. Journal of International Marketing, 19(1), 82-101.

Doz, Y. L., \& Prahalad, C. K. (1980). How MNCs cope with host-government intervention. Harvard Business Review, 58(2), 149-157.

Eroglu, S. (1992). The internationalization process of franchise systems: A conceptual model. International Marketing Review, 9(5), 19-30.

Fladmoe-Lindquist, K. (1996). International franchising: Capabilities and development. Journal of Business Venturing, 11(5), 419-438.

Fundação Dom Cabral (2011). Ranking das transnacionais brasileiras: Crescimento $e$ gestão sustentável no exterior. Retrieved from http://www.fdc.org.br/professoresepesquisa/ publicacoes/Paginas/publicacao-detalhe. aspx?publicacao $=18171$

Ghemawat, P. (2007). Managing differences: The central challenge of global strategy. Harvard Business Review, 85(3), 59-68.

Guide Franchising (2016). From Brazil to the World. Brazilian Franchising Association, 11(11), 9-18. 
Hilal, A., \& Hemais, C. A. (2003). O processo de internacionalização na ótica da escola nórdica: Evidências empíricas em empresas brasileiras. Revista de Administração Contemporânea, 7(1), 109-124.

Huszagh, S. M., Huszagh, F. W., \& McIntyre, F. S. (1992). International franchising in the context of competitive strategy and the theory of the firm. International Marketing Review, 9(5), 5-18.

Jain, S. C. (1989). Standardization of international marketing strategy: Some research hypotheses. The Journal of Marketing, 53(1). 70-79.

Jell-Ojobor, M., \& Windsperger, J. (2013). The choice of governance modes of international franchise firms an integrative model. Proceedings of the Annual International Society of Franchising, Zhuhai, China, 27.

Johanson, J. , \& Mattsson, Y. L.-G. (1988). Internationalization in industrial systems: A network approach. In N. Hood \& J.-E. Vahlne (Eds.), Strategies in global competition (pp. 287314). London: Croom Helm.

Johanson, J., \& Vahlne, J. E. (1977). The internationalization process of the firm: A model of knowledge development and increasing foreign market commitments. Journal of international business studies, 8(1), 23-32.

Johanson, J., \& Vahlne, J. E. (2006). Commitment and opportunity development in the internationalization process: A note on the Uppsala internationalization process model. Management International Review, 46(2), 165-178.

Khauaja, D. (2010). Gestão de marcas na estratégia de internacionalização de empresas: Estudo com franqueadoras brasileiras (Tese de doutorado). Faculdade de Economia, Administração e Contabilidade, Universidade de Sao Paulo, Sao Paulo, SP, Brasil.
Krippendorff, K. (2004). Content analsis: An introduction to its methodology. Thousand Oaks: Sage.

Levitt, T. (1993). The globalization of markets. In R. Z. Aliber \& R. W. Click (Eds.), Readings in international business: A decision approach (pp. 249-266). Cambridge: MIT Press.

Marques, D. S. P. (2006). Internacionalização de Franquias: Um mapeamento sobre a presença de redes brasileiras no exterior (Dissertação de mestrado). Faculdade de Economia, Administração e Contabilidade, Universidade de Sao Paulo, São Paulo, SP, Brasil.

Marques, D. S. P., Merlo, E. M., \& Lucchesi, C. A. M. (2005). Os motivos envolvidos na internacionalização de franquias brasileiras. FACEF Pesquisa-Desenvolvimento e Gestão, 8(2), 5-18.

McIntyre, F. S., \& Huszagh, S. M. (1995). Internationalization of franchise systems. Journal of International Marketing, 3(4), 39-56.

Melo, P., Andreassi, T., \& Oliveira, M. M., Jr. (2012). Fusão e internacionalização de franquias no segmento de alimentação: $O$ caso TrendFoods e China in Box. In P.L.R. Melo \& T. Andreassi (Orgs.), Franquias brasileiras: Estratégia, empreendedorismo, inovação e internacionalização (pp. 107-122). Sao Paulo: Cengage Learning.

Melo, P. L., Borini, F. M., \& Cunha, J. A. C. (2014). Percepçóes de valor e elementos estruturantes das microfranquias. Revista de Administração Contemporânea, 18(3), 328-350.

Mendelsohn, M. (1994). A essência do franchising. São Paulo: Difusão de Educação e Cultura.

Merrilees, B. (2014). International franchising: Evolution of theory and practice. Journal of Marketing Channels, 21(3), 133-142.

Oliveira, E. C., \& Crescitelli, E. (2008). Comunicação da marca global via site: Padronizada 
ou adaptada? Anais do Seminário em Administração SEMEAD, São Paulo, SP, Brasil, 11.

Özsomer, A., \& Simonin, B. L. (2004). Marketing program standardization: A cross-country exploration. International Journal of Research in Marketing, 21(4), 397-419.

Porter, M. E. (1991). Towards a dynamic theory of strategy. Strategic Management Journal, 12(S2), 95-117.

Quinn, B., \& Alexander, N. (2002). International retail franchising: A conceptual framework. International Journal of Retail \& Distribution Management, 30(5), 264-276.

Rocha, T., Borini, F., \& Spers, E. (2010). A internacionalização das franquias brasileiras (Vol. 1). São Paulo: ESPM.

Rocha, T., Borini, F., \& Spers, E. (2012). Aspectos mercadológicos e estratégicos da internacionalização das franquias brasileiras (Vol. 2). São Paulo: ESPM.

Rocha, T., Borini, F., Spers, E., Khauaja, D., Camargo, M. A., Ogasavara, M. H., \& Melo, P. L. (2014). Estágios da internacionalização das franquias brasileiras (Vol. 3). São Paulo: ESPM.

Rocha, T., \& Silva, S. (2011). The adaptation vs. standardization dilemma: The case of an american company in Brazil. Internext, 6(1), 63-83.

Roth, K., Schweiger, D. M., \& Morrison, A. J. (1991). Global strategy implementation at the business unit level: Operational capabilities and administrative mechanisms. Journal of International Business Studies, 22(3), 369-402.

Sanghavi, N. (2003). Internationalization of retail/service business strategic opportunities and challenges. Proceedings of the International
Conference on Global Business and Economic Development, Bangkok, 7.

Schweiger, D. M., \& Morrison, A. J. (1991). Global strategy implementation at the business unit level: Operational capabilities and administrative mechanisms. Journal of International Business Studies, 22(3), 369-402.

Silva, C. D., Mendes, D. A. P., \& Gomes, J. S. (2002). O controle gerencial na internacionalização de franquias: $\mathrm{O}$ caso de uma empresa brasileira. Anais do Congresso de Contabilidade, Porto, Portugal, 4.

Stake, R. E. (2013). Multiple case study analysis. New York: Guilford Press.

Toledo, L. A., \& Shiraishi, G. D. F. (2009). Estudo de caso em pesquisas exploratórias qualitativas: Um ensaio para a proposta de protocolo do estudo de caso. Revista da FAE, 12(1), 103-119.

Vahle, J. E., \& Johanson, J. (2013). The Uppsala model on evolution of the multinational business enterprise. International Marketing Review, 30(3), 189-210.

Yin, R. K. (2015). Estudo de caso: Planejamento e métodos. Porto Alegre: Bookman.

Yip, G. S. (1995). Instructor's manual: Total global strategy: Managing for worldwide competitive advantage. Englewood Cliffs: Prentice Hall.

Zou, S., \& Cavusgil, S. T. (1996). Global strategy: A review and an integrated conceptual framework. European Journal of Marketing, 30(1), 52-69.

Zou, S., \& Cavusgil, S. T. (2002). The GMS: A broad conceptualization of global marketing strategy and its effect on firm performance. Journal of Marketing, 66(4), 40-56. 


\section{About the authors:}

1. Maria Adriana de A. P. Camargo, PhD. Student in Management at ESPM - Brazil.

E-mail: maria.adriana@acad.espm.br

2. Thelma Valéria Rocha, PhD. in Management at ESPM - Brazil. E-mail: tvrocha@espm.br

3. Susana Costa e Silva, PhD. in Marketing at University College Dublin - Ireland.

E-mail: ssilva@porto.ucp.pt

\section{Contribution of each author:}

\begin{tabular}{|c|c|c|c|}
\hline Contribution & $\begin{array}{c}\text { Maria Adriana } \\
\text { de A. P. Camargo }\end{array}$ & $\begin{array}{c}\text { Thelma Valéria } \\
\text { Rocha }\end{array}$ & $\begin{array}{c}\text { Susana Costa } \\
\text { e Silva }\end{array}$ \\
\hline 1. Definition of research problem & $\sqrt{ }$ & $\sqrt{ }$ & \\
\hline 2. Development of hypotheses or research questions (empirical studies) & $\sqrt{ }$ & $\sqrt{ }$ & $\sqrt{ }$ \\
\hline 3. Development of theoretical propositions (theoretical Work) & & $\sqrt{ }$ & \\
\hline 4. Theoretical foundation/ Literature review & $\sqrt{ }$ & $\sqrt{ }$ & $\sqrt{ }$ \\
\hline 5. Definition of methodological procedures & $\sqrt{ }$ & $\sqrt{ }$ & \\
\hline 6. Data collection & $\sqrt{ }$ & & \\
\hline 7. Statistical analysis & $\sqrt{ }$ & & \\
\hline 8. Analysis and interpretation of data & $\sqrt{ }$ & $\sqrt{ }$ & $\sqrt{ }$ \\
\hline 9. Critical revision of the manuscript & $\sqrt{ }$ & $\sqrt{ }$ & $\sqrt{ }$ \\
\hline 10. Manuscript Writing & $\sqrt{ }$ & $\sqrt{ }$ & $\sqrt{ }$ \\
\hline
\end{tabular}

